\section{Nutrient release in leaf litter}

SIR-Kundu has suggested ${ }^{1}$ that the contribution of litter to plant nutrition at the onset of monsoon compared to microbial biomass for the dry tropical forest and savanna ecosystems is larger than we reported $^{2}$. We still believe that most of the nutrients needed to initiate plant growth at the onset of the rainy season in these ecosystems probably comes from mineralization of microbial cells instead of decomposing litter.

Plant growth and foliage expansion in nutrient-poor, dry tropical ecosystems occur rapidly at the start of the rainy season. Because of the lack of any conspicuous time-lag, substantial plant biomass develops within the first 2-3 weeks. This process requires a substantial flush of nutrients available for plants. It is known that in the absence of an exogenous supply of available nutrients, the net release of nutrients from most decomposing litter species occurs only after a period of net immobilization $^{3}$. On the other hand, the microbial communities of droughty soils are pre-adapted to moisture stress and accumulate intracellular solutes under conditions of low water potential ${ }^{4}$. In soils with wet and dry seasons, increase in water potential may cause a seasonal turnover of microbial biomass by inducing microbial plasmoptysis whereupon all cellular constituents, including nitrogen and phosphorus, are released ${ }^{s}$. Increased soil nutrients due to drying and subsequent rewetting is largely derived from dead microbial cells ${ }^{6}$. Expansion of microbivore populations at the start of the rainy season induces further release of microbial nutrients.

Our studies show that the pulsed turnover of microbial biomass in the early part (first 4 weeks) of the rainy season contributes about $32 \mathrm{~kg}$ per ha $\mathrm{N}$ and $13.2 \mathrm{~kg}$ per ha $\mathrm{P}$ in forest soils and about $25 \mathrm{~kg}$ per ha $\mathrm{N}$ and $10 \mathrm{~kg}$ per ha $\mathrm{P}$ in savanna soils? These values compare with total rainy season (12-14 weeks) litter decomposition releases of about $22 \mathrm{~kg}$ per ha $\mathrm{N}$ and $1.4 \mathrm{~kg}$ per ha $\mathrm{P}$ for forest ecosystems and $19 \mathrm{~kg}$ per ha $\mathrm{N}$ and $1.8 \mathrm{~kg}$ per ha $\mathrm{P}$ for savanna ecosystems ${ }^{8}$. These release rates from litter decomposition are markedly lower compared with the values cited by Kundu from ecosystems in Zaire and Guatemala, none of which is a dry tropical site.

1. Kundu, D.K. Nature 344, 203 (1990).

2. Singh, J.S., Raghubanshi, A.S., Singh, R.S. \& Srivastava, S.C. Nature 338, 499-500 (1989).

3. Upadhyay, V.P. \& Singh, J.S. J. Ecol. 77, 127-146 (1989).

4. Sparling, G.P., Milne, J.G. \& Vincent, K.W. N.Z.T. Agric Res. 30, 79-84 (1987)

5. Kieft, R.L., Soroker, E. \& Firestone, M.K. Soil Biol. Biochem. 19, 119-126 (1987)

6. Sparling, G.P. \& Ross, D.J. Plant Soil 105, 163-167 (1988).

7. Srivastava, S.C. thesis (Banaras Hindu Univ., Varansi, 1989)

8. Singh, K.P. \& Misra, R. Structure and Functioning of Natural, Modified and Silvicultural Ecosystems of Eastern Uttar Pradesh. (Tech. Rep., Banaras Hindu Univ., 1979).
We suggest that the pulsed release of microbial nutrients at the beginning of the rainy season not only supports the initiation of plant growth, it also helps shorten the net nutrient immobilization phase of litter decomposition. Net nutrient mobilization during the subsequent release phase of litter decomposition sustains further biomass accumulation in the later part of the growing season.

A. S. RAGHUBANSHI S. C. SRIVASTAVA R. S. SINGH J. S. SINGH

Department of Botany,

Banaras Hindu University,

Varanasi 221005,

India

\section{Halothane and anaesthesia}

SIR-Evers et al. ${ }^{1}$ reported that pharmacologically relevant concentrations of halothane bind saturably to a unique environment in brain. These findings seemed to be a significant contribution to our understanding of the molecular basis of anaesthesia, an area that remains controversial $^{2,3}$. Recently, the same investigators published a correction ${ }^{1}$, in which they reported that anaesthetic-induced depression of halothane uptake rather than a finite number of binding sites was responsible for the "saturable" binding of this anaesthetic in brain. Nonetheless, they suggested the short ${ }^{19} \mathrm{~F}$ NMR spin-spin relaxation time $\left(T_{2}\right)$ is likely to be pharmacologically relevant. Using a similar method, we find the short $T_{2}$ environment

\begin{tabular}{lc}
\hline \multicolumn{2}{c}{$\begin{array}{c}{ }^{19} \mathrm{~F} \text { SPIN-SPIN RELAXATION TIMES }\left(T_{2}\right) \\
\text { OF HALOTHANE }\end{array}$} \\
\hline \multicolumn{1}{c}{ Tissue } & $T_{2}(\mathrm{~ms})$ \\
Brain & $3.9 \pm 0.2(4)$ \\
Packed red blood cells & $3.0 \pm 0.2(3)$ \\
Liver & $5.6 \pm 0.2(3)$ \\
Kidney & $4.4 ; 4.1$ \\
Serum & $44.0 \pm 2.6(3)$ \\
\hline
\end{tabular}

Rats were anaesthetized with $4 \%$ halothane for $1 \mathrm{~h}$, decapitated, and tissues from individual animals transferred to a gas-tight syringe fitted with an 18-gauge needle. $T_{2}$ and halothane concentrations were determined by ${ }^{19} \mathrm{~F} \mathrm{NMR}{ }^{4}$. $T$, values represent $\bar{x}$ \pm s.e.m. with the number of experiments in parentheses. In some experiments, mixed trunk blood from anaesthetized rats was collected in NMR tubes. After centrifugation, halothane concentrations and spinspin relaxation times of packed red blood cells and serum were determined as described elsewhere for other tissues ${ }^{4}$. When brain samples equilibrated with anaesthetic saturated buffer were examined without adequate centrifugation, biexponential semilogarithmic relaxation profiles (long and short $T_{2}$ relaxation times) were obtained, presumably resulting from a heterogeneity of environments. The presence of compartmental heterogeneity was also readily demonstrable in spectra of liver which exhibited two signals of comparable intensity (separated by 0.23 p.p.m.); one with a long $T_{2}$ (31 ms) and the other with a short $T_{2}(5.6 \mathrm{~ms})$ for halothane is not unique to brain, but is present in other tissues (see table).

We measured halothane concentrations of $2.4 \pm 0.2 \mathrm{mM}$ in the brain with the anaesthetic in a short $T_{2}$ environment (3.9 $\mathrm{ms}$ ) in rats exposed to $4 \%(\mathrm{v} / \mathrm{v})$ halothane for $60 \mathrm{~min}$. These findings are comparable to those of Evers et al. ${ }^{1}$. But we also measured short $T_{2}$ environments for halothane in packed red blood cells and other peripheral tissues of anaesthetized rats (see table).

These findings indicate that a highly immobilized environment for halothane is not unique to brain. Although the presence of this environment for halothane in brain and other tissues may be of interest, our findings indicate it is not directly related to the molecular mechanisms of anaesthesia.

Herman J. C. Yeh

Laboratory of Analytical Chemistry, ERIC J. MOODY PHIL SKOLNICK

Laboratory of Neuroscience,

NIDDK, National Institutes of Health,

Bethesda,

Maryland 20892, USA

1. Evers, A.S., Berkowitz, B.A. \& d'Avignon, D.A. Nature 303 157-160 (1987); correction Nature 341, 766 (1989).

2. Franks, N.P. \& Lieb, W.P. Trends pharmac. Sci. 8, 169 $174(1987)$

3. Forman, S.A. \& Miller, K.W. Trends pharmac. Sci. 10 449-452 (1989).

4. Moody, E., Yeh, H.J.C. \& Skolnick, P. in Alcohol Reinforcement (eds Koob, G. et al.) (Birkhauser, Boston, in the press)

- An earlier version of this letter was received on 14 December 1988.

\section{Beach pebbles explained}

SIR-Wald (Nature 345, 211; 1990) seems unaware that the presence of a planar structure in a rock will strongly influence the final proportions of a beach pebble. Most rocks contain structures such as sedimentary bedding, metamorphic foliation or igneous lamination, and will be shaped to flattened ovoids of the type he describes, the plane of flattening being parallel to the planar structure.

This is easily verified by direct observation on almost any beach. Even in apparently structureless rocks such as quartzite there is likely to be a preferred orientation of the crystallographic axes of the quartz crystals such as to cause a biased pebble shape. To avoid such complications, one has to be choosy about the rock: a fine-grained intrusive igneous rock might do, such as the microgranite of Ailsa Craig in Scotland, long used in the manufacture of curling stones because of its small grain size and homogeneity.

Department of Geology and

W. ASHCROFT

Petroleum Geology,

University of Aberdeen,

Marischal College,

Aberdeen AB9 1AS, UK 